\title{
Reflexões Sobre a Queixa Muda da Anoréxica
}

\author{
Leda Verdiani Tfouni ${ }^{1}$ \\ Cláudia Grisi Mouraria \\ Beatriz Helena Vieira Maranghetti Ferriolli \\ Universidade de São Paulo - Ribeirão Preto
}

\begin{abstract}
RESUMO - Considerando-se que o caráter primordial do significante se exerce em relação ao sujeito, buscamos compreender o sujeito anoréxico através da investigação do significante "corpo". O material foi constituído por uma entrevista semi-estruturada, de noventa minutos, realizada com uma paciente diagnosticada como anoréxica. A análise dos dados foi qualitativa, seguindo a análise do discurso "francesa" e a psicanálise lacaniana, e permitiu constatar que o significante "corpo" atrelou-se a "peso" e "alimentação" na mesma cadeia discursiva. Desse modo, essa cadeia significante veio compor a ordem da identidade e da alteridade do sujeito, sob a égide do (sem) controle. Concluímos que a queixa muda da anoréxica, que se materializou como a recusa alimentar, era dirigida ao Outro como uma tentativa de alcançar sua alteridade.
\end{abstract}

Palavras-chave: anorexia; cadeia significante; identidade; alteridade.

\section{Reflections About the Mute Complaint of Anorexia}

\begin{abstract}
Taking into consideration that the main characteristic of the signifier is practiced in relation to the subject, we attempted to understand the anorexic subject through an investigation of the specific signifier "body". The study material was formed by a ninety minutes semi-structured interview with a patient diagnosed as anorexic. Data analysis was qualitative, following the "French" discourse analysis and Lacanian psychoanalysis. The analysis indicated that the signifier "body" was linked to "weight" and "feeding" in the same discursive chain. Thus, this significant chain established the order of identity and alterity, governed by (lack of) control. The conclusion is that the anorexic's silent complaint, materialized through a refusal to eat, is directed at the Other in an attempt to attain alterity.
\end{abstract}

Keywords: anorexia; significant chain; identity; alterity.

Em nossa sociedade, profundamente impregnada pela lógica cartesiana, temos dois modos facilmente discriminados - e de certa forma antagônicos - de significar o corpo. De um lado apresenta-se um corpo anatômico/biológico, pedindo para satisfazer suas necessidades. De outro, temos um corpo subjetivo/imaginário/simbólico que requer a satisfação de suas demandas e desejos (Lacan, 1998a; 1996).

Entre esses "dois" corpos há um sujeito, que ora se manifesta mais aqui, ora mais ali, escapando de uma precisão; mas que, em essência, busca (algo). Nesse interregno é que se configura o singular como um fato de repetição real, como aquilo que desenha na rede simbólica as coordenadas do equívoco.

Incorporamos aqui a visão de que o processo de estruturação do sujeito através da entrada no simbólico implica a articulação do Real (do organismo enquanto massa amorfa e indistinta), do simbólico e do imaginário (Lacan, 1953/1996). Então, ao falarmos de corpo não falamos mais apenas de carne, músculos e tendões. Falamos de um sujeito imerso na linguagem; falamos de deslizamentos significantes, de sentidos e significações. Falamos de um sujeito que está constantemente escapando e confundindo-se com o eu e/ ou o corpo.

Assim como tendões e músculos constituem o sujeito/o corpo, a linguagem o significa e o constitui em sua infindável

1 Endereço para correspondência: Rua Maria Octavia P. Villa, 71, Ribeirão Preto, SP. CEP: 14021-047.E-mail: 1vtfouni@usp.br incompletude. Desse modo, o sujeito funda na linguagem sua importância ontológica.

O sintoma e a lalíngua (lalangue, real da língua, de acordo com Milner, 1987) assemelham-se por não conseguirem revelar toda sua questão, podendo apenas expressar aquilo que "escapa" do inconsciente, dizendo-se, assim, pela incompletude. Por esse motivo, o sintoma anoréxico foi tomado neste trabalho como uma queixa, isto é, como uma parte do sujeito do inconsciente que pôde ser enunciada através de complexas atitudes sintetizadas na recusa alimentar.

Essa queixa é, em essência, um canal de comunicação falho, marcado pela articulação inconsciente de uma falta perfeitamente singular ao eixo de significação no qual esse sujeito se constitui. Além disso, por ser uma queixa, é dirigida a um destinatário. Denominamos essa queixa de muda por tratar-se de uma recusa do sujeito ao Outro, o Grande Outro lacaniano, entendido aqui como a ordem do simbólico ou do discurso. Assim como podemos não "dar ouvidos" ao outro/Outro, podemos não dirigir-lhe a voz. É justamente a esse emudecimento que buscamos emprestar uma escuta neste trabalho.

\section{Psicopatologia Psicanalítica da Anorexia}

Um dos principais crivos para se diagnosticar a anorexia nervosa é a eliminação de qualquer causa orgânica geradora de inapetência. De acordo com a Associação Americana de 
Psiquiatria (DSM-IV, 1995) os critérios diagnósticos que compõem o quadro de anorexia são: perda de peso corporal 85\% abaixo do esperado; medo intenso de ganhar peso; perturbação no modo de vivenciar o peso ou a forma do corpo; nas mulheres pós-menarca, amenorréia. Inicialmente, não lhes ocorre inapetência (exceto em quadros evoluídos de desnutrição), mas sim uma recusa, aversão ou repúdio à comida. Desse modo, o que existe é uma luta ativa e secreta contra a fome.

Com relação ainda aos constantes questionamentos sobre o fato de a mídia e os valores culturais serem responsáveis pela origem e emancipação do quadro anoréxico, podemos afirmar que não. Em nossa opinião, esses fatores não seriam causais, mas sim gatilhos de uma dinâmica pré-existente. Segundo Gordon, a anorexia é um distúrbio que utiliza na composição de seu quadro uma linguagem contemporânea típica (Tridenti \& Bocchia, 1994). Em um estudo correlacionado Strauman et al. (1991 conforme citado em Crahay \& Goffinet, 2001) afirmam que o comportamento anoréxico sofre influência da cultura, normas e regras sociais, havendo, também, uma predisposição psíquica. Com base nessas afirmações, podemos citar Dunker (2000), que faz uma interessante correlação entre a dinâmica psíquica da anoréxica e as configurações ideológicas e culturais, fortemente orientadas para o consumo de imagem. Segundo o autor, existe nesse quadro: “(...) a construção de uma afinidade imaginária e ideológica entre a condição de objeto para o uso do outro e a condição feminina" (Dunker, 2000, p.18). Desse modo, os regimes e a valorização de corpos muito magros seriam os gatilhos disparados pelo imaginário contemporâneo e/ou pela linguagem contemporânea típica e não os fatores causais do quadro anoréxico.

A respeito da delimitação da anorexia dentro de uma estrutura específica, ainda hoje existem muitas divergências quanto à compreensão da estrutura em que a anorexia melhor se encaixaria ou, até mesmo, se ela própria configuraria uma nova estrutura. De modo geral, o que mais encontramos na literatura são referências a estruturas perversas ou histéricas (Bidaud, 1998; Cañete, Vitalle \& Silva, 2008; Fernandes, 2006, Nunes, 2006). Não nos aprofundaremos nessa questão, mas investigaremos os principais pontos teóricos que a psicanálise lacaniana ilumina nesse quadro ainda tão misterioso.

Os estudos de Freud e Breuer (1893-1895/1987) sobre a histeria introduzem uma possibilidade de escuta às mulheres até então acostumadas ao uso de espartilhos e oprimidas pela dominação masculina dentro da cultura ocidental (Robell, 1997). Para a autora "É como se agora o espartilho tivesse atravessado o corpo das mulheres e forçasse seu interior" (p.16).

Para Bruch (1982), o radicalismo da negação da fome na anoréxica está a serviço de uma busca por autonomia e poder. Acrescentaríamos, ainda, a busca de uma onipotência massacrante sobre o Outro.

A recusa anoréxica exerce a função de marcar um desejo próprio, distinto do desejo do Outro primordial. Segundo Lacan (1998b, p.634) "É a criança a quem se alimenta com mais amor que recusa o alimento e joga com sua recusa como um desejo (anorexia mental)". Tal movimento de recusa, disfarçado sob uma negação da fome (vestígio primeiro da relação do sujeito com o Outro), é o traço mais marcante da anorexia, ou ainda, é o que constitui a própria marca da anoréxica.
A criança, ao demandar que a mãe (Outro primordial) sacie sua necessidade, simultaneamente demanda à mãe $\mathrm{a}$ doação de seu amor. A interação que ocorre entre mãe-criança no momento em que a criança demanda o amor materno é fundamental no processo de reconhecimento do filho como sujeito. Esse processo, iniciado em tenra idade, será finalizado com o complexo de Édipo.

Tanto Lacan quanto Leclaire parecem estar de acordo sobre o fato de que pode haver na anorexia uma amarração tal na dualidade mãe-criança, que esta se transforma em uma unicidade. Assim, criança e desejo do Outro se tornam sinônimos, sendo a recusa anoréxica dirigida ao Outro que, por não entender sua demanda, responde cumulando-a com tanta ceva. Na anorexia, a percepção dessa primeira dualidade relacional com o Outro primordial ocorre de tal modo que o sujeito sente-se enclausurado, em uma remitência maciça ao Outro que o aprisionaria e sufocaria com tanta ceva. Leclaire (1977) refere que a origem da anorexia ocorre quando um sujeito foi tão bem alimentado (o autor utiliza o termo "cevado") por sua mãe que a demanda de amor da criança não é percebida pela mãe, permanecendo, dessa forma, sufocada.

Isso ocorre muito possivelmente porque a mãe respondera somente à superfície da demanda, tendo deixado de lado aquilo que constitui o seu fundo: a expectativa de amor. A partir daí, para reiterar sua demanda, o sujeito não tem outra via senão recusar a comida, com que fora tão plenamente satisfeito. Sobre esse mecanismo, Lacan (1998b, p.634) indaga: "Afinal de contas a criança ao recusar-se a satisfazer a demanda da mãe, não está exigindo que a mãe tenha um desejo para além dela, porque é esta a via que lhe falta em direção ao desejo?"

Lacan situa a anorexia no momento em que o objeto da satisfação da necessidade substitui o objeto da satisfação simbólica, obturando essa satisfação, que se encontra justamente na rejeição do objeto. Afirma o autor: "Apenas isso pode explicar a verdadeira função de um sintoma como o da anorexia mental. Já lhes disse que a anorexia mental não é um não comer, mas um comer nada. (...) Nada, isso é justamente algo que existe no plano simbólico" (Lacan, 1995, p.188). Isso ocorre na anorexia, segundo o autor, pois o Outro primordial “(...) que também tem suas idéias sobre as necessidades dela (criança), se intromete nisso e, no lugar daquilo que não tem, empanturra-a com a papinha sufocante daquilo que tem, ou seja, confunde seus cuidados com o dom de seu amor" (Lacan, 1995, p.188).

Lacan (1997, p.116) afirma que "só o amor permite ao gozo condescender ao desejo". A mãe (da) anoréxica não pode dar esse amor, pois atende a seu próprio desejo, que a faz gozar, confundindo sua capacidade de cuidado com a doação de seu amor e, deste modo, "cumulando" a filha. A mãe quer que sua filha seja plena e completa para, com isso, satisfazer seu próprio desejo de completude. Essa dificuldade de discriminar entre demanda e desejo gera uma alienação total do sujeito ao desejo do Outro.

Segundo Freud (1915/1996a), o desejo surge a partir de um reinvestimento psíquico ocasionado por uma lembrança (traço mnésico) que está ligado à satisfação de uma pulsão. A pulsão é uma sensação/excitação que ocorre no sujeito e que o mobiliza a satisfazê-la. Sempre que reaparecer a sensação, ocorrerá uma mobilização psíquica e retornará a imagem mnésica da primeira situação de satisfação. Esse movimento 
é o desejo, e a presença da percepção 'do objeto' requerido é a realização desse desejo. No entanto, Lacan (1973/1998b) alerta que as pulsões só poderão aparecer como pulsões ${ }^{2}$ parciais; sendo assim, o desejo é sempre metonímico e o alvo pulsional sempre impossível de ser realizado porque não há uma inscrição no real, mas sim, na estrutura do sujeito. “... não existe, em última análise, satisfação do desejo na realidade... a dimensão do desejo não tem outra realidade que não uma realidade psíquica" (Dor, 1989, p.141).

Para que se articule um desejo é necessário haver duas demandas, porém a mãe que empanturra não pede, nem deixa que a criança abra a boca para pedir. Assim, a questão (queixa) da anoréxica só pode existir como um segredo mudo: uma "queixa muda".

Parece que o modo encontrado pelo sujeito anoréxico de afirmar e conservar seu apetite de desejo é recusando a comida, para ratificar que esse significante (inicialmente pertencente ao âmbito da necessidade - pulsão) agora está colado e dirigido ao âmbito do desejo. A equação que norteia essa atitude postula que, satisfazendo-se a necessidade mata-se o desejo.

Essa equação leva a anoréxica a manter obstinadamente sua insatisfação, tanto da necessidade fisiológica como do desejo. Ou seja, o modo encontrado de manter seu desejo insatisfeito (justamente de fazê-lo existir) é manter seu apetite (tomado como fome) insatisfeito.

Entretanto, como a fome, o apetite, o imaginário, o simbólico e o real coexistem então se deve manter a fome insatisfeita até o limite em que morrer de fome e viver de desejo constituem o lastro da singularidade para que o sujeito liberte-se de sua indiferenciação. A forma encontrada de distinguir-se é negar o desejo do Outro/outro, renegando assim seu próprio desejo, já que o desejo do sujeito é o desejo do Outro.

"É justamente aqui que se encontra o ponto contraditório, paradoxal, e mortífero da encruzilhada da anoréxica: negando a fome, isto é, negando ser via de acesso ao desejo do Outro, deve renegar a si mesma, na medida em que é o desejo do Outro (...). Respondendo tragicamente à ignorância do Outro acerca de seu ser, tenta abrir no Outro uma brecha à sua existência, a saber, ao seu desejo. $\mathrm{O}$ 'não tenho fome', proferido placidamente pelo sujeito, é como uma bofetada lançada ao Outro" (Mouraria, 2005, p 40).

Em lugar de expressar-se verbalmente, seja porque sua causa é muito dolorosa, seja porque lhe é desconhecida, a anoréxica escreve os significantes no corpo como uma metáfora. A magreza se faz signo, como aquilo que se "faz ver", expondo-se ao olhar do outro. Fazendo-se signo, pede uma resposta, porém não se interroga; por isso expõe-se como uma queixa-muda (inconsciente) em seu corpo. Ao buscar realizar o descolamento entre eu/ Outro, via desejo, a anoréxica o faz de uma maneira equivocada. Ao tentar descolar-se do Outro e sustentar-se a si própria, busca sair de uma posição de impotência para ocupar uma de onipotência narcísica, confundindo alteridade com independência. $\mathrm{O}$

2 A pulsão refere-se a um impulso psíquico e deve ser diferenciada dos instintos, os quais são comportamentos hereditariamente fixados e predeterminados. Com o intuito de marcar esta diferença, Freud (1915/1996a) cunhou o termo pulsão ao se referir às exigências de trabalho impostas ao aparelho psíquico, visando satisfazer desejos ou atingir objetivos necessários à descarga das tensões que residem no aparelho psíquico. corpo, subjugado a essa condição, constitui uma barreira para algo que não quer se expressar, que é de ser desejo do desejo do outro/Outro.

Assim, o que se evidencia nessa dinâmica é a presença de um desejo que se articula, não somente como desejo de reconhecimento, mas como reconhecimento de um desejo do desejo do outro/Outro. Sendo o significante (corpo) a dimensão essencial dessa dinâmica, quanto mais o sujeito se afirma como querendo sair dessa cadeia significante, mais entra e se integra nela, tornando-se ele próprio um signo dessa cadeia.

A recusa incessante do sujeito em pagar essa “... dívida que não contraiu é o último recurso de tudo aquilo que se manifesta do inconsciente sob a forma da reprodução sintomática" (Lacan, 1999, p.254-55).

\section{Método}

\section{Participante}

Ao priorizar a singularidade, optamos por um estudo de caso. A paciente em questão foi diagnosticada como anoréxica e encontrava-se em atendimento no Ambulatório de Transtornos Alimentares do Hospital das Clínicas da Faculdade de Medicina da USP/Ribeirão Preto. Apresentava o quadro há mais de 10 anos, tinha nível superior na área da saúde e trabalhava na mesma instituição em que fazia o seguimento médico. O sujeito voluntariamente aceitou participar após ter sido explicado todos os procedimentos que envolviam a pesquisa e os critérios éticos do sigilo. As entrevistas foram realizadas e gravadas pela própria pesquisadora em sala restrita, mediante a assinatura de um Consentimento Informado e após uma sessão de rapport. Optou-se pela entrevista semi-estruturada para garantir que alguns tópicos fossem abordados sem que novos dados ficassem menosprezados. Todas as entrevistas foram literalmente transcritas, para posterior análise do material lingüístico-discursivo.

\section{Procedimento de análise de dados}

A análise dos dados seguiu o paradigma indiciário (Ginzburg, 1989) orientado pela Análise de Discurso de filiação francesa (Pêcheux, 1990; 1995). A escolha da Análise do Discurso como metodologia nos permitiu verificar, através da análise das formações ideológicas $(\mathrm{FI})^{3}$ e discursivas $(\mathrm{FD})^{4}$, a maneira como o sujeito localiza seu sintoma na relação com o significante corpo.

3 Para a $\mathrm{AD}$ a formação ideológica funcionam como normas identificadoras do sujeito e seus valores, aparecendo discursivamente sob uma evidência da transparência do sentido e camuflando sua "dependência constitutiva" (PÊCHEUX, 1995:160)

4 Para a AD, a formação discursiva é "... a matriz de sentidos que regula o que o sujeito pode e deve dizer e, também, o que não pode e não deve ser dito" (COURTINE, 1994:7). Tais FDs são materializadas linguisticamente por indícios discursivos de que "algo não vai bem" nos enunciados do sujeito, fato este que se revela pelo uso das elipses, hesitações, atos falhos, etc., os quais vêm marcar uma ruptura na cadeia significante. 


\section{Resultados e Discussão}

Os fatos discursivos que foram recortados para a análise são os deslizamentos metafóricos ${ }^{5}$, cujo funcionamento possibilitou que se entendesse melhor a questão da psicopatologia desse sujeito.

\section{Recorte 1}

"S: Olha eu sei... sempre tive é... capacidade de discernir quem é uma pessoa gorda quem é uma pessoa magra, fora de mim. A minha dificuldade é auto-imagem, a de ter um padrão assim. Porque eu... apesar do peso, eu tenho consciência do peso e da... assim... em termos numéricos, massa corporal assim, eu sei que tá baixo, é... tudo mais, teoricamente eu sei, eu sei que eu estou magra, eu sei que esse peso é... um peso baixo. Mas no sentir não é assim, eu me sinto gorda e pesada, assim, qualquer cem gramas pra mim é um absurdo, você não precisa da balança, você sabe que engordou, não precisa. Então assim, a minha dificuldade é auto-imagem e mesmo assim, se você se olhar no espelho, você se enxerga gorda no espelho apesar de você estar magra (...)

apesar ... assim, você tem osso saliente, no concreto você sabe que você está magra, você vê que seu osso tá as-, tem osso saliente, você olha.... às vezes o abdômen tá encovado, alguma coisa mais, seu rosto tá fino, cê sabe que você tá mais magra, mas eu olhando no espelho, dependendo do dia que eu olho eu não enxergo assim, eu acho que eu estou com o formato arredondado, eu acho que eu tô com o seio grande, o abdômen grande, é... então, assim ... eu sinto diferente, principalmente quando eu ganho algumas gramas, eu fico procurando onde é que ele tá acumulado, esses gramas. Tanto é que eu não gosto de olhar no espelho, dependendo do dia eu olho eu não enxergo assim, porque dependendo do meu dia e do meu estado de espírito e da minha condição do dia, eu me enxergo de uma forma correta, tem dia que eu me enxergo magra, normal como deveria ser, e tem dia que não, porque eu já tenho essa distorção, apesar de toda medicação que você toma, eu não consigo ter essa... é... essa noção, essa distorção persiste.

Tal qual Lacan (1998a) nos anuncia, o sujeito encontra-se cindido entre verdade e saber. Para o autor, este lugar de queda do sujeito não é outro senão o do objeto-causa-do desejo. No recorte acima, o sujeito vive um dilema entre o saber, materializado pelo significante "eu sei..." e o que parece ser a sua verdade, ou seja: "Eu estou com o formato arredondado..."

Apesar de as evidências denunciarem um corpo anoréxico (baixo peso na balança, ossos salientes e abdômen encovado), o sujeito vê um fantasma na medida em que confunde o real do seu corpo anoréxico com " ... o efeito do desejo arcaico inconsciente que serve de matriz para os desejos atuais, conscientes e inconscientes" (Chemama, 1995, p.71). O que o sujeito enxerga é um fantasma que, segundo Freud

5 Entende-se por metáfora a substituição de uma palavra por outra, sendo que a palavra substituta conserva algo do sentido da palavra substituída. A metáfora atesta a supremacia do significante sobre o sujeito e ".. o determina lá mesmo onde ele (o sujeito) crê escapar a toda determinação de uma linguagem que ele pensa controlar" (DOR,1989:45).
(1914/1918/1980), é a representação imaginária que o sujeito faz de si, pode ser consciente (e apresentar-se sob a forma de devaneio), pré-consciente ou inconsciente. O fantasma pode se manifestar por palavras, fonemas, partes do corpo ou objetos associados.

Scazufca (1998), contemplando essa questão do fantasma, relata que a anoréxica encontra-se totalmente alienada em um "vínculo de repetições" que não consegue desmantelar, porque responde a um "mandato superegóico". O sujeito torna-se escravo de si mesmo, pois na medida em que precisa subverter a qualquer preço a ordem determinante imposta pelo outro (ceva), acaba por estratificar-se em um lugar determinado por ele próprio, lugar este que o aprisiona.

A identidade do sujeito anoréxico é hermenêutica e encontra-se centrada em uma imagem fantasmática e em significantes que remetem à comida, dietas, corpo e peso, conforme enunciado pelo sujeito: "...tem dia que eu me enxergo magra, normal como deveria ser ..." . O uso do verbo no futuro do pretérito denota que o estado normal deveria ser "magra", mas não é o que ocorre, pois o sujeito não se enxerga dessa forma. O sujeito anuncia que "fora de mim" eu sei, mas "no sentir não é assim", ou seja, quando olha na balança (objetividade) sabe que está magra, no entanto, 'não sente' e “... quando ganho alguma grama fico procurando onde está (a)cumulado".

Através da insistência do sujeito em repetir: "eu sei", "eu me sinto", "eu olho" e o deslizamento do pronome para "você sabe", "você olha", nota-se que ele identifica-se no gozo, na exatidão do "nomeado" ou o Outro "que me olha". Para Hekier e Miller (1996), quem é nomeado anoréxico, assim se posiciona, é uma questão de identificação com o significante do Outro.

\section{Recorte 2}

S: “(...) às vezes percebo que eu fico assim... chocada, que você percebe que você tá magra além da conta, quando vem uma pessoa estranha fala, ou então, é... tipo assim (...) as pacientes às vezes comentam com as meninas, com as funcionárias que também trabalham comigo, "nossa, a senhora é magra demais! Ela tá doente?!” E começam a perguntar, então quando alguém estranho fala, aí às vezes cai um pouquinho a ficha, cai e não cai, assim, eu sinto que na, na prática, é assim, mas no sentir eu continuo me sentindo gorda, pesada, que aquilo ali não é meu. Eu posso olhar uma fotografia de 10/15 anos atrás, eu me acho imensa nas fotos. Eu não me identifico com aquela $N$ que estava na foto anterior. E eu perdi assim completamente o parâmetro de peso normal, eu assim, por cálculos assim, por cálculos eu sei meu peso ideal, mas assim eu não tenho peso agora, eu até falo pras meninas, eu não tenho um peso agora que me deixe contente, eu me sinto bem perdendo peso. Se eu ganhar peso, eu não posso dizer ganhar tenho que dizer recuperar, eu me sinto péssima! Então eu fujo da balança. (...) Tem hora que aquele peso já não, já não me satisfaz, eu sempre quero ter menos, menos, menos. Eu me lembro que quanto mais você perde, mais você quer perder. Você perde a noção de que aquilo te compromete fisicamente, que pode ser grave, que pode chegar um ponto que você assim ... não tenha reversão mais". 
A idéia que impera é da perda, materializada nos significantes: "não me satisfaz", "eu sempre quero ter menos, menos, menos", "quanto mais você perde, mais você quer perder". Para Lacan (1998a), o desejo não é articulado, mas articulável na cadeia metonímica. Pode parecer, em um primeiro momento, que o único desejo desse sujeito é o da morte, porém, na contigüidade discursiva, através do recorte abaixo, é anunciado logo no início que o sujeito não consegue acreditar que seu quadro clínico seja tão grave a ponto de levá-lo à morte.

\section{Recorte 3}

\section{"E: Você não acredita nisso?}

S: Não, eu não consigo acreditar... nisso (possibilidade de morte em decorrência da anorexia). Por mais assim, ruim que eu esteja na condição de internação que eu estive ano passado, é.... eu tive muitas alterações metabólicas, mesmo assim, tudo assim... eles falavam que, é... que poderia não tá acreditando que aquilo ali me fosse fazer mal, porque eu peso muito pior, muito menor do que aquele e estava conseguindo sobreviver, mas que depois de tanto tempo, de tantos anos assim, o organismo chega num certo ponto que ele não reage mais, pode chegar num certo ponto de você ter uma parada cardíaca e não ter reversão... né? Então assim que ... que eu não estava enxergando aquilo, que eu estava tão assim ... obcecada com a intenção de morrer, com a ... ideação (difícil entender) suicida mesmo, que eи não queria viver mais, que aquilo ali não estava me assustando, e isso assustava a equipe, não a mim, a mim aquilo lá não preocupava nem um pouco."

Ainda em relação à questão da morte, Freud (1914/1918/1980) revela que os fantasmas servem para refinar as lembranças ou sublimá-las, e acrescenta que se pode pensar nos três enigmas, que para o autor constituem os fantasmas originários: o fantasma acerca das origens (cena originária), da sexualidade (sedução) e da morte (castração). A anoréxica já não deseja mais, pois para que um desejo se articule é necessário haver duas demandas, porém o outro que alimenta e cumula, não é capaz de identificar a demanda da criança. O sujeito está para lá de saciado, empanturrado, mesmo sem comer. É nesse sentido que o fantasma se torna real para a anoréxica, pois sua imagem no espelho reflete uma sublimação ou eufemismo de seu próprio corpo.

Lacan (1991) em seu seminário sobre a ética fala da tragédia de Antígona que se apresenta como "auto-nomos" ou regendo a si mesma, sem intervenções de agentes externos. Tal qual Antígona, a anoréxica se apresenta como uma autônoma que exercita o poder de ser o que é (ou de acordo com os recortes acima: "eu sei..."; "eu sou..."). Segundo Lacan (1991 p.341): “Antígona se apresenta como 'autonomos', pura e simples relação do ser humano com aquilo que ocorre de ele ser miraculosamente portador do corte significante, que lhe confere o poder intransponível de ser o que é, contra tudo e contra todos" (grifo nosso). Antígona marca a fronteira entre dois mundos (o dos vivos e o dos mortos ou a lei dos homens e a dos deuses), denominada por Lacan de "entre-dois", região que se situa entre o real e o simbólico.
No caso da anoréxica, tanto quanto em Antígona, o lugar "entre-dois" não pode permanecer por muito tempo, pois é a morte invadindo a fronteira da vida ou a pulsão da morte.

Observando os dados, pode-se demarcar nos recortes apresentados que o sujeito realizou um deslizamento metafórico que vai da alimentação para a identidade.

O pronome "aquilo" revela a dificuldade de o sujeito nomear algo que o "empanturrava"|"cumula". O significante "aquilo" aparece, diversas vezes, como uma metáfora na cadeia que engloba os significantes: "corpo", "caminho", "identidade", "peso". "Aquilo" também aparece como um deslizamento do significante "alimentação", que é visto como algo agressivo pelo sujeito.

Ao comentar sobre seu corpo ou sobre a anorexia, o sujeito complementa diversas vezes o pronome "aquilo" com uso do pronome demonstrativo de lugar ("ali"), produzindo um efeito de que "aquilo" estaria distante. Este fato discursivo leva-nos a supor que o pronome "aquilo" pode ser compreendido ao mesmo tempo como metáfora do corpo e como metáfora da anorexia. Assim, corpo e anorexia constituem um mesmo eixo significante.

Os significantes "peso", "alimentação" e "gramas" aparecem, em alguns momentos, como metáforas do Outro (desejo do Outro), constituindo a via de acesso desse Outro sobre o sujeito anoréxico. Parece que o objetivo do sujeito é criar um desejo no Outro

\section{Recorte 4}

"S: (...) eu usava diurético, laxante, esses remédios desses que eles fazem propaganda na televisão pra regime, eu tinha bicicleta ergométrica, eu ficava à base assim de duas horas pedalando na bicicleta ergométrica. Eu moro assim na V. T., perto do Centro, eu ia fazer o curso de computação, alguma coisa, eu fazia caminhadas mil, eu ia a pé eu voltava a pé. Eu não sei como que eu aguentava, né, e assim, ingerindo pouco. Então assim, foi uma coisa assim, que na época (não inteligivel) (....) em uma das internações eu tava muito ansiosa, então virava e mexia eu ia parar na Unidade de Emergência, eu não tinha nada, mas assim... (...) Com medo, porque eu passei uma situação assim que tive assim... uma crise de hipoglicemia, que eu tive tipo uma crise convulsiva, por causa da hipoglicemia, então é um mal estar muito ruim, então a partir dessa época eu fiquei com medo, daquele mal estar, de sentir aquilo. E... que eu nunca assim, sentia, mas assim era uma fraqueza, uma coisa assim, mas não chegava ao extremo que eu cheguei, né. Medicação eu não tomava, antidepressivo eu não tomava, fingia que tomava, mas eu não tomava nada... E assim, era completamente fora, não achava que eu não precisava atendimento psiquiátrico e não precisava de medicação. E a partir desse momento que eu comecei a sentir dessa forma tão mal, que eu fiquei com uma ansiedade tal que eu tinha... tipo uma síndrome do pânico, tinha um mal estar físico todo daquilo, sabe; mas ao examinar não tinha nada ... Aí eu senti a necessidade de então tomar a medicação, aí eu aceitei, a partir dai eu comecei a levar a sério e a ... é ... a assumir o tratamento, a entender o que que era que eu tava tendo, aí eu aceitava que o meu diagnóstico era anorexia, que não era um problema meramente físico, não era." 
O sujeito utiliza frequentemente, em seu discurso, o advérbio "assim". Tal insistência nos leva a discutir esse termo que podemos considerar como elíptico, já que a elipse pode ser considerada como uma entidade lingüística desprovida de objetividade e que sustenta, via de regra, uma indeterminação. Em latim, ellipsis significa falta. De acordo com Cunha e Cintra (1984, p.613), “elipse é a omissão de um termo que o contexto ou a situação permitem facilmente suprir". No entanto, o que observamos no recorte acima com a reincidência do advérbio "assim", é que existe uma opacidade que não permite que o sentido seja identificado rapidamente, mas somente através da retroação na cadeia significante. Parece que o advérbio faz materializar uma contradição ou embate do sujeito consigo mesmo, uma não aceitação de que seu problema não era "meramente" físico. O sujeito inicia sua narrativa falando dos exercícios físicos que realizava, faz uma denegação “...não achava que não precisava” (ou dito de outra forma: achava que precisava), para terminar dizendo “...aí eu aceitava que meu diagnóstico era anorexia, que não era um problema meramente físico, não era”.

Podemos destacar ainda nesse recorte que o sujeito vive uma dúvida em relação ao seu diagnóstico, em seguida foram ocorrendo complicações em relação a sua saúde e finalmente, quando ele parece ter se convencido do diagnóstico, utiliza o verbo no pretérito imperfeito “... não precisava... aí eu aceitava que o meu diagnóstico era anorexia...". Um dos casos em que se utiliza esse tempo verbal é para expressar uma incerteza quanto às realizações futuras.

\section{Recorte 5}

"S: Não eu comia, comia assim... porque... não sei se era, eu usava o alimento como ansiolítico, eu acho. Chegou um ponto que às vezes eu usava o laxante como ansiolítico. Achava que meu intestino tinha que funcionar, porque o que entrava, o que entra - até hoje eu penso assim - tem que sair, mesmo que for o mínimo tem, não pode ficar muito tempo aqui dentro. Eu, eu não admito a sensação de ter o alimento muito tempo dentro de mim... ele entra, porque eu tenho fome, normal, (fala baixo) assim, é... eu não posso mentir e fala assim olha "eu não tenho fome", eu tenho fome, vontade, tenho vontade, mas eu não tenho a coragem de comer, tipo assim, eu tenho vontade de comer um doce, eu vejo um doce, nossa eu morro de vontade de comer, eu posso até pegar um pedaço e pôr na boca, mas eu não consigo engolir, eu cuspo fora. E se eu chego a comer eu fico com um sentimento de culpa tal que eu quero que aquilo... saia de qualquer maneira, mas assim eu não consigo provocar o vômito, eu não não faço isso (fala muito baixo), então assim, eu prefiro não comer, mesmo com toda vontade que eu tenho eu prefiro não comer, pra não ter que provocar e fazer nada. (...) então eu prefiro assim (ininteligível), então assim eu não como pão, arroz, feijão, então assim tem um monte de coisa que eu па̃o...”

O corpo é metáfora da questão anoréxica, a qual aponta dois possíveis "caminhos" à existência do sujeito anoréxico: ou ele continua sendo "empanturrado" pelo Outro ou rompe com este Outro, drasticamente, para buscar sua mítica auto- nomia e/ou sua identidade autônoma ("auto-nomos"), através da recusa à comida (metáfora do Outro).

Como sabemos, a questão alimentar vem tratar da lógica da separação e da constituição da identidade, as quais se encontram diretamente relacionadas à origem da imagem corporal e ao desejo do outro/Outro. Inicialmente, o sujeito precisa ocupar o lugar de ser o desejo do Outro, para existir. Entretanto, na anorexia, ocorre que o sujeito permanece amarrado a esse momento. Por isso, o sujeito sente-se "cumulado", agredido pelo Outro, que o imobiliza em uma existência sem alteridade. Dessa maneira, sua imagem corporal encontra-se "enorme", "gorda", "acumulada" pelos "gramas" (peso) - pelo Outro.

O próprio sujeito anuncia a causa de seu sintoma quando diz: "Então assim, a minha dificuldade é auto-imagem..." (recorte 1). A imagem corporal é "a sintese viva de nossas experiências emocionais" e "está ligada ao sujeito e à sua história”. Trata-se de uma "encarnação simbólica e inconsciente do sujeito desejante (...), reporta o sujeito do desejo a seu gozar (...), é um intersubjetivo imaginário marcado de pronto no ser humano pela dimensão simbólica (...) suporte do narcisismo" (Dolto, 2001 p. 10). Logo, o corpo é o mediador entre o sujeito e o mundo.

Ao referir-se à sua imagem, o sujeito anoréxico está falando de seu desejo, de seu gozo e de sua identidade. Está falando que ao olhar-se no "espelho", isto é, em sua relação de espelhamento com outro/Outro, sente-se "cumulada”, pesada, gorda. Sobre isso, o sujeito diz: "apesar de (você) estar magra... de, no concreto, você saber que está magra", "mas eu olhando no espelho, dependendo do dia que eu olho, eu não enxergo assim”.

A origem da imagem corporal é dada pela síntese das experiências emocionais e parece ser a esse âmbito que a questão anoréxica se reporta, ao tentar delimitar sua existência através da refutação da comida (primeira via de relação com o desejo do Outro primordial). Para isso, o sujeito busca mostrar e reconhecer-se através da distinção entre necessidade, demanda e desejo; como se, refutando a comida, pudesse mostrar ao Outro que sua demanda é da ordem do desejo e não só da "necessidade".

A satisfação da necessidade aparece como "o engodo em que a demanda de amor é esmagada, remetendo o sujeito ao sono em que ele freqüenta os limbos do ser, deixando que este (o Outro) fale nele" (Lacan, 1998c, p.633). Assim, a recusa veemente da comida seria uma tentativa de mostrar ao Outro - que não sabe distinguir seus desejos - e a si mesma, que a falta seria uma via a ser.

Essa luta contra a fome aparece na análise dessa entrevista como o caminho que deverá ser percorrido pelo sujeito para viabilizar sua existência através do sintoma.

Sobre o sintoma, Freud nos aponta que a necessidade de repetir uma mesma recusa seria o último recurso de tudo aquilo que se manifesta do inconsciente sob a forma da reprodução sintomática (Lacan, 1999, p.255). Então, respondendo tragicamente à ignorância do Outro acerca de seu ser e tentando abrir neste uma brecha à sua existência - a saber: ao seu desejo - o sujeito anoréxico lança, através da inanição, uma bofetada no Outro. 
Outra característica da anorexia que pudemos investigar através dessa entrevista foi o comportamento de inanição auto-imposta. Tal investigação se deu a partir do deslizamento do significante "auto-controle". Quando o sujeito fala do "auto-controle" com relação à alimentação e ao corpo, estes aparecem como as "única(s) coisa(s)" sobre as quais o sujeito tem controle em sua vida. Desse modo, essa fala vem corroborar o que dissemos sobre os significantes "identidade" e "corpo". No momento em que realiza estes deslizamentos, o sujeito aproxima o "auto-controle" de algo agressivo e punitivo e nomeia esse processo de "auto-fagia" e "suicídio lento". No entanto, apesar de termos claramente a presença de dois termos que implicam a morte orgânica, o sujeito parece não acreditar que essa hipótese venha a ocorrer, pois o emagrecimento é visto fonte de alteridade/vida.

Seguindo o raciocínio no qual o significante "alimentação" seria uma metáfora do Outro e o objetivo da anoréxica seria ver-se livre deste, podemos compreender que esse sujeito está verbalizando que sua recusa é do "mais" que vem do Outro; justamente "aquilo" que a empanturra e sufoca seu ser. Assim, a dialética da anoréxica com o outro/Outro se faz através de comer versus não-comer (recusar). Pudemos dar continuidade ao entendimento da radicalidade desse quadro e da avaliação do risco de morte, que o sujeito apreende sobre seu estado, através da análise da cadeia significante que envolve os temas relacionados à ansiedade, mal estar e medo.

A partir da subjetivação do corpo em "mal-estar físico" e "ansiedade", o sujeito aproxima-se, em alguns momentos, de uma percepção real do risco de morte que corre e relata sentir medo. Entretanto, refuta que esse risco seja decorrente da anorexia. Ou seja, a "morte" almejada, na anorexia, não é uma morte concreta, mas é a morte de uma identidade (constituída a partir imagem corporal). Fica evidente tal distinção no recorte em que o sujeito comenta que as internações devidas à anorexia não a assustavam, enquanto as devidas à ansiedade e ao mal-estar físico, sim. Os significantes "mal estar físico" e "ansiedade" aparecem como metonímias.

Nesse enlaçamento discursivo, o pronome "aquilo" reaparece na mesma cadeia do significante peso, enquanto contrapõe "aquilo" a algo físico. Assim, "aquilo" (enquanto metáfora da anorexia) não despertava preocupação, ao passo que a "parada cardíaca" sim. Essa contraposição nos faz perceber que para o sujeito a anorexia não gerava a possibilidade de uma morte concreta/física, mas apenas de uma morte simbólica. Exatamente porque "... el fantasma de su propria muerte es el primer objeto que el sujeto tiene para poner en juego en esta dialéctica y, en efecto lo hace, como sabemos por muchésimos hechos, la anorexia mental" (Hekier \& Miller, 1996, p.113).

Ao relatar uma de suas internações em que estava muito ansiosa, o sujeito contrapõe as internações decorrentes da anorexia no $\mathrm{HC}$ (agendadas e ordenadas pelos médicos) às internações na Unidade de Emergência (que eram frequentes), sendo que neste último caso a procura pelo atendimento havia ocorrido espontaneamente, em decorrência de sua ansiedade. A partir daí, "medo da morte", "ansiedade" e "mal-estar físico", começam a atrelar-se em uma rede significante constitutiva de um discurso onde o sujeito emerge frágil e sem controle.

\section{Considerações Finais}

Notamos que a luta anoréxica em direção à autonomia ou à identidade autônoma é co(n)fundida com o conceito de alteridade. A aquisição da alteridade se caracteriza por, justamente, reconhecer a participação do Outro em nossa existência, porém separado de nós, e isso impede que o sujeito deixe-se "cumular". É nesse ponto que surge o paradoxo, a encruzilhada anoréxica: para não ser determinada até a morte pelo Outro ela tentará matá-lo, matando sua fome e a si mesma, uma vez que não existimos simbolicamente sem o Outro, nem concretamente sem a comida.

A condição de uso pelo outro/Outro se estenderia a toda uma ideologia social onde a condição do feminino deve ocupar uma posição de objeto à satisfação de outro(s)-Outro(s). É necessário esclarecer que quando tratamos do feminino, de acordo com Freud (1996b), referimo-nos à estrutura psíquica da histeria, e não aos traços biológicos e/ou sociológicos do sujeito empírico. André (1998), seguindo Freud (1996c) e Lacan (1985), estabelece uma relação entre a estrutura histérica e a mulher: decorre daí que a anorexia encontra-se relacionada com as questões do feminino. $\mathrm{Na}$ anorexia essa condição é negada através da recusa à consistência do Outro. Segundo Lacan (1987, p.17), essa recusa dirige-se "ao mundo da oferta de objetos e de imagens e ao imperialismo que lhe corresponde", ganhando, assim, "contornos de denúncia" à invasão do outro.

Neste artigo pretendeu-se aprofundar a teoria lacaniana sobre a dinâmica da anorexia a partir de um estudo de caso. Pudemos confirmar através do deslizamento metafórico entre o grande Outro (ou desejo do Outro) e o significantes 'corpo' que a relação eu - Outro aparece marcada por uma 'cumulação' do eu, onde o sujeito sente-se e percebe-se por demais empanturrado do Outro e esvaziado de si. Desse modo, insistir para que o sujeito ganhe peso/corpo significaria reforçar a questão anoréxica. Tendo em vista tais aspectos, acreditamos que toda e qualquer decisão sobre os caminhos a serem tomados no tratamento da anorexia demandam reflexões que vão além do corpo biológico e requerem especificidades/ singularidades no tratamento.

\section{Referências}

André, S. (1998). O que quer uma mulher? Rio de Janeiro: Jorge Zahar.

Associação Americana de Psiquiatria (1995). Manual Diagnóstico e Estatística de Transtornos Mentais (DSM-IV). Porto Alegre: Artes Médicas.

Bidaud, E. (1998). Anorexia mental, ascese mística: Uma abordagem psicanalítica. Rio de Janeiro: Companhia de Freud.

Bruch, H. (1982). Anorexia nervosa: therapy and theory. American Journal of Psychiatry, 139, 1531-1538.

Cañeta, M. C. V., Vitalle, M. S. de S., \& Silva, F. C. (2008). Anorexia nervosa: Estudo de caso com uma abordagem de sucesso. Fractal, Revista de Psicologia, 20, 377-386.

Chemama, R. (1995). Dicionário de psicanálise Larousse. Porto Alegre: Artes Médicas. 
Courtine, J. J. (1994). Le tissu de la memoire. Langages, n.114. Paris: Larousse.

Crahay, M., \& Goffinet, C. (2001). Reggards Croisés sur l'Anorexie. Liège: Éditions de l'Université de Liège.

Cunha, C., \& Lindley Cintra, L. F. (1984). Nova Gramática do Português Contemporâneo. Lisboa: João Sá da Costa.

Dolto, F. (2001). Esquema corporal e imagem do corpo. A Imagem Inconsciente do Corpo. São Paulo: Perspectiva, coleção estudos, 9-24.

Dor, J. (1989). Introdução à leitura de Lacan: o inconsciente estruturado como linguagem. Porto Alegre: Artes Médicas (Originalmente publicado em 1985).

Dunker, C. I. L. (2000). Vontade incontrolável de comer nada. Revista Viver Psicologia, Psiquiatria, Neurociência, Psicossomática, Psicopedagogia. São Paulo, 7(88), 16.

Fernandes, M. H. (2006). Transtornos Alimentares. São Paulo: Casa do Psicólogo.

Freud, S., \& Breuer, J. (1987). Estudos sobre a histeria. In S. Freud (Ed.), Obras completas. (J. Salomão, Trad.). Rio de Janeiro: Imago, v.II (originalmente publicado em 1893-1895).

Freud, S. (1996a). A pulsão e suas vicissitudes. Edição Standard Brasileira das Obras Psicológicas Completas de Sigmund Freud [ESB]. Rio de Janeiro: Imago, s/d. v.XIV (originalmente publicado em 1915).

Freud, S. (1996b). Três ensaios sobre a teoria da sexualidade. Edição Standard Brasileira das Obras Psicológicas Completas de Sigmund Freud [ESB], v. VII. Rio de Janeiro: Imago (pp. 119-231). (originalmente publicado em 1905).

Freud, S. (1996c). Feminilidade. Novas conferências introdutórias sobre psicanálise e outros trabalhos. Edição Standard Brasileira das Obras Psicológicas Completas de Sigmund Freud [ESB], vol. XXII. Rio de Janeiro: Imago, (originalmente publicado em1933[1932]). p. 113-134.

Freud, S. (1980). História de uma neurose infantil. In Edição Standard Brasileira das Obras Psicológicas Completas de Sigmund Freud [ESB]. Rio de Janeiro: Imago, v.XVII, p. 19151 (Originalmente publicado em 1918[1914]).

Ginzburg, C. (1989). Sinais: Raízes de um paradigma indiciário. Mitos, emblemas, sinais: Morfologia e história. São Paulo: Companhia das Letras. p.143-179.

Hekier, M., \& Miller, C. (1996). Anorexia-Bulimia: desejo de nada. Buenos Aires: Paidós.

Lacan, J. (1985). O Seminário, livro 20: mais, ainda. Rio de Janeiro: Jorge Zahar.

Lacan, J. (1987). Os complexos familiares. Rio de Janeiro: Jorge Zahar (Trabalho original publicado em 1938).

Lacan, J. (1991). A essência da tragédia. Um comentário da Antígona de Sófocles. In J. Lacan (Ed.), O seminário 7: a ética da psicanálise (pp. 295-346). Rio de Janeiro: Jorge Zahar.
Lacan, J. (1995). O objeto de Fetiche. O Seminário: A relação de objeto, livro 4. Rio de Janeiro: Jorge Zahar, 153-202.

Lacan, J. (1996). Real, Simbólico e Imaginário. Palestra proferida por Jacques Lacan na Societé Française Psychanalyse (M. S. Gomes \& S. Mangaravite, Trad.). Papéis, n.4 (Palestra proferida em 1953).

Lacan, J. (1997). O Seminário: A angústia, livro 10. Rio de Janeiro: Jorge Zahar.

Lacan, J. (1998a). Subversão do sujeito e dialética do desejo no inconsciente freudiano. Escritos (Vera Ribeiro, Trad.) Rio de Janeiro: Jorge Zahar, 793-842.

Lacan, J. (1998b). Do amor à libido. O Seminário, livro 11: Os quatro conceitos fundamentais da psicanálise. Rio de Janeiro: Jorge Zahar, 177-189 (Originalmente publicado em 1973).

Lacan, J. (1998c). A direção do tratamento e os princípios de seu poder. Escritos. (V. Ribeiro, Trad.) Rio de Janeiro: Jorge Zahar, 591-652.

Lacan, J. (1999). A fantasia para além do princípio do prazer. $O$ Seminário: As Formações do Inconsciente, livro 5. 241-260.

Leclaire, S. (1977). Mata-se uma criança - um estudo sobre o narcisismo primário e a pulsão de morte (A. S. Styzei, Trad.). Rio de Janeiro: Jorge Zahar.

Milner, J. C. (1987). O amor da língua. (A. C. Jesuino, Trad.) Porto Alegre: Artes Médicas.

Mouraria, C. G. (2005). Um Corpo: a queixa muda da anoréxica: Ribeirão Preto. Dissertação de Mestrado. FFCLRP/USP.

Nunes, M. A. A. (2006). Transtornos Alimentares. Porto Alegre: Art-Med.

Pêcheux, M. (1990). O discurso: estrutura ou acontecimento (E. P. Orlandi, Trad.). Campinas: Pontes Editores.

Pêcheux, M. (1995). Semântica e discurso: uma crítica à afirmação do óbvio. (E. P. Orlandi, Trad.). Campinas: Editora da Unicamp.

Robell, S. (1997). A mulher escondida - A anorexia nervosa em nossa cultura. São Paulo: Summus Ed.

Scazufca, A. C. (1998). Anorexia-bulimia: sintomas do desejo. Boletim de Novidades Pulsional. São Paulo:Escuta, ano XI, n.106. 15-27.

Tridenti, A., \& Bocchia, S. (1994). Il Fenômeno AnoressicoBulimico. Uma Tentativa di Comprensione Unitaria dei Disturbi del Comportamento Alimentare. Milano, Itália: Masson S.P.A. 